\title{
An Application of Activity Based Costing in Higher Learning Institution: A Local Case Study
}

\author{
Anbalagan Krishnan \\ Curtin University of Technology \\ E-Mail: anbalagan.k@curtin.edu.my
}

\begin{abstract}
The widespread environmental change has forced many organizations to change and rethink their business and competitive strategies, particularly cost management system, in order to achieve the competitive edge in the marketplace. Successful organizations are those that are able to improve quality, lower costs and efficiency of operations and eliminate products and services that incur losses. This explains why some organizations are successful while others fail. An organization costing system is a system that helps the management with the strategy planning while the system plays an important role in providing accurate cost information about the products and customers. In other words, the costing management system is important to provide timely and quality information to help managers in their decision making process. To achieve this, many organizations shift their focus from conventional or traditional costing system to an increasingly popular cost methodology system that is Activity- Based Costing (ABC). This system simply collects cost in functional activity cost pools and then applies costs to products/services using individual cost drivers (Brignall, 1997). Initially when this system was introduced, it was only popular among the manufacturing context; however, now it also pulls attention of the service sectors. Kock (1995) noted that it is now more important than ever to have access good information in decision-making in the management of service firms. A number of research and studies reveal how the ABC system in the service sectors has effectively kept the operational cost at marginal level and still be able to provide better customer service at the same time. Thus, this case study analyses how an ABC costing system that improves operations and to better meet the needs of University customers in a more cost - effective manner.
\end{abstract}

Keywords: Conventional Costing System, Activity - Based Costing, Quality of Information 


\section{INTRODUCTION}

A country's economy in large depends on industries particularly service sectors such as insurance company, financial institutions, health service, transportation. As more corporate sectors venturing into service industries create competition, they are required to provide a quality customer service at reasonable cost. A number of service firms have gone into bankruptcy as a result of poor control over escalating overhead cost. Thus, the survival of a firm in service industry is largely depending on the availability of timely and quality information for decision-making and the ability to keep the operation cost at marginal level.

Consequently, cost and management accounting concepts and techniques are not only used in manufacturing sectors but also in service sectors to provide cost information for decision-making. A study by Horngren (1995) found that the focus of cost management should be on decisions and the various cost management techniques, systems and measurements that spur and help managers to make wiser economic decisions. Of the many available cost management systems, research reveals that a bigger number of companies' uses Activity- based costing (ABC) method in comparison with the traditional costing system in providing timely and quality cost information (Adams, 1996; Brignall, 1997; Cagwin \& Bouwman, 2002; Innes \& Mitchell, 1997). However, the implementation of such system is costly and often the idea of implementing the system is drop as a result of time consumption and lack of expertise. In some cases, the cost for carrying out the ABC analysis is higher than the returns. Nevertheless, there is a growing body of literature, which argues that, compared to the traditional costing systems, Activity- Based costing (ABC) offers important advantages to organizations (Adams, 1996).

\section{LITERATURE REVIEW}

In 1923, J. Maurice Clark coined the phrase 'different costs for different purposes', but most companies only have one costing system, which is used for all purposes: stock valuation, planning, control and decision-making (Brignall, 1997). Prior to the introduction of ABC costing system, a number of companies, particularly manufacturing sectors, used a traditional costing system called volume- based costing system, which is volume-based cost driver such as direct-labour hours, direct labour cost, or machine hours. At most the cost are classified into two main parts that are Product cost which is a cost assigned to goods that were either purchased or manufactured for resale and Period cost where administration and selling are recognized as expenses during the period in which they are incurred. If inventories are manufactured, the product cost is relatively 
easy to trace to production job but manufacturing overhead is not easily traced to jobs as these costs often bear no direct relationship with individual jobs or units of product (Hilton, 2005). The conventional or traditional accounting system allocates the manufacturing overhead to the products either plantwide overhead rate or on two-stage allocation system. The former allocates cost on a single activity base for the entire factory but the latter assigns manufacturing overhead cost based on departmental activities. Under this system, at the first stage, the manufacturing cost is collected into cost pools and then attached to products by a method based on unit volume of production such as direct labour hours (Brignall, 1997). Thus, the allocation of manufacturing cost depends on the types of resources that the products consume. The greater the products consume the resource, the higher the overhead attached to the products based on one particular activity base such as direct labour hour, machine hour or direct labour cost. Furthermore, this system allows for cost distortions, which will be greater in business units with a higher proportion of overhead costs (Baird, Harrison, \& Reeve, 2004).

While this approach has the advantage of simplicity, it will result in systematic miscosting where overheads are not volume driven (Innes \& Mitchell, 1997). Researchers noted that this system failed to reflect other resource or cost of activities that added value to the production (Adams, 1996; Innes \& Mitchell 1997; Johnson \& Kaplan, 1987). Other than that, Copper and Kaplan (1987, cited in Adams, 1996) assert that traditional cost and management accounting systems such as those based on standard costing and absorption costing have measured company performance imperfectly because they have not kept up with the developments in production technology and consumerism. Therefore, to avoid biased cost reporting, the allocation of overheads to cost objects should not be based on a common volume-related measure, such as direct labour hour but on the groups of activities which generate those overheads (Kaplan, 1987, cited in Adams, 1996).

An overhead allocation based on activity centers avoids a common consequence of traditional output-based costing system particularly under cost low volume products. A study conducted by Innes and Mictchell (1997) found that overheads based on activity centers facilitate the targeting of unnecessary, wasteful, resource usage and the costly effects of over-complex ways of running a business process. This technique, which is popularly known as Activity-Based costing (ABC), is a 'system that focuses attention on the costs of various activities required to produce a product or service' (Baird et al., 2004: 384). This system is in favor of many organizations in order to provide "true" cost information for their strategic decision-making. 
The ABC, first developed by Cooper and Kaplan (e.g. Cooper, 1988; Cooper and Kaplan, 1988), is a system that will reduce the level of arbitrary cost allocations associated with "traditional" costing systems and result in more accurate product cost (Baird et al., 2004). Many authors have advocated the benefits of ABC, and a number of studies have provided empirical evidence to support those benefits (Anderson, 1995; Foster and Swenson, 1997; McGowan and Klammer, 1997; Norris, 1994; Swenson, 1995 all cited in Baird et al., 2004). Spicer (1993, cited in Adams, 1996) noted that besides providing more accurate product costing, $\mathrm{ABC}$ also improves the basis upon which strategic decisions, involving resource allocation, product mix, pricing and marketing, are made. Cagwin and Bouwman (2002) further listed authors who are in the opinion that, the application of $\mathrm{ABC}$ is more effective in specific environmental conditions (enabling conditions) such as manufacturing complexity (Jones, 1991), environments with specialty product costs (Srinidhi, 1992) and diverse (multiple different) business environments (Cooper \& Kaplan, 1988). Furthermore, the refined treatment of overhead cost by using ABC system can facilitate the identification of how individual customer influences the cost of supply (Innes \& Mitchell, 1997). Bellis-Jones (1989) found that when ABC is used in this way, customer profitability profiles and analysis are possible and market strategy is enhanced by this intelligence (cited in Innes \& Mitchell, 1997).

In the beginning, $\mathrm{ABC}$ cost management system was common in the manufacturing environment where the identification of activities associated with the products was still less complex and in some instances the activities were direct. However, now even the service sectors adopt $\mathrm{ABC}$ cost management, acknowledging the importance of cost information for survival in the increased competition. A number of researches revealed successful applications of ABC in private as well in public service sectors, such as financial institutions, hotel sectors, health centers, transport companies, and telecommunication (Adams, 1996; Cagwin \& Bouwman, 2002; Innes and Mitchell, 1997; Kock, 1995; Kullven \& Mattson, 1994; Lambert and Whitworth, 1996). Thus, the service sectors shift the cost management focus from conventional costing system to the ABC system.

\section{ABC IN SERVICE INDUSTRIES}

$\mathrm{ABC}$ is a useful decision making-framework for economic analysis in service sectors, particularly in the areas of planning, control and decision-making. Cooper and Kaplan (1991) assert that service firms can benefit form using ABC as they have the same set of issues as manufactures, e.g. analyzing operating expenses and performing service activities that demand resources (cited in Kock, 1995). They further noted that it 
is also an effective tool in service firms for tracing cost to services produced and a helpful tool in implementing total quality thinking in service firms as it encourages management to analyze activities and determine their value to the customers. For instance, the application of ABC system in hospital helps managers to better assess operational efficiency, establishes more meaningful comparisons of financial performance with other hospitals, and optimizes the mix of service offered to patients (King et al., 1994, cited in Adams, 1996). The research further revealed that ABC generates information that enables managers to identify opportunities for cost savings and provides them with an improved basis for budget constructions. Therefore, the costing system based on ABC model would help service sectors to understand the cost and value of service activities that are essential to control escalating operational costs.

ABC cost system also helps to eliminate non- valued added activities that consume organizations' resources without any benefits for the organizations. With this analysis, the service sector could focus its resources on activities that add value to a customer and provide economic benefits. However, this does not mean that understanding the activities that drive cost and eliminate non-value added activities compromise the service quality rendered to its customers. Kock (1995) asserts that customers demand services that often drive business expenses up without a corresponding increase in revenue and, thus, firms that could quantify these costs are in the best position to control them. All in all, the objective is to eliminate any activities that do not add to the service provided and with this, costs can be reduced without compromising the service offered to the customers.

This research paper explores the application of Activity- Based Costing in a higher learning institution particularly in a University and how it contributes to its business and operational strategic decision-making. To maintain the anonymity of the subject in this case study, the subject will be referred to as "the university".

\section{RESEARCH OBJECTIVE AND METHODOLOGY}

The purpose of this case study is to study the application of Activity Based Costing in service sectors particularly higher learning institutions and whether this cost system provides better control over the cost in comparison with the traditional costing system. Appropriate costing system is necessary as the university is under great pressure to lower costs and improve the quality and efficiency of operations due to a competitive education industry. Particularly, the university requires cost information to improve the quality, timeliness, and efficiency of the activities they perform, and to understand accurately the cost of the individual department at the university. Thus, the objectives of this research are as follows: 
1. A costing system that identify and eliminate non-value added costs. These are the costs of activities that can be eliminated with no deterioration of service quality and performances.

2. A costing system that determines the efficiency and effectiveness of all major activities performed in the University.

3. A costing system that identify and evaluate new activities that can improve the future performance of the University.

The research methodology of this case study is a combination of both descriptive and quantitative analyses as follows:

1. Descriptive analyses

A study of the University Annual Report

A study of the Department budgets and general ledger items

2. Quantitative analyses

Computation of Overhead rate

Suggestion of New cost Model

A costing model based on Activity Based Costing is developed for Registrar office as an illustration. The data for this case study were collected from the Registrar office department in order to compute the overhead base on Activity Base Costing system.

\section{THE CASE ANALYSIS}

The university was established in Malaysia seven years ago with a joint venture partner with one of the foreign university. The university recognized major drawbacks with current costing system for not being able to detect and control the escalating operational cost. The present cost management system does not provide accurate cost information in order to facilitate the decision planning particularly in eliminating nonadded value activities. Based on analysis, the current costing system does not achieve the objective of directing and controlling operational activities. For example, in directing, the university requires cost data to be classified according to each department's activity in order to avoid any activities consuming university resources without adding any value. As for controlling, the university requires a cost tool to measure the department's performance. Therefore, the university requires a cost management system that not only provides analysis of its products and services but also helps the management with the strategic planning and control of the organization's overall functions.

The university's department operation is managed through budgetary control of responsibility centers, which is lacking of 'true' cost data information. This system 
requires each department head to forecast numbers in the preset budget. The preset budget only outlines department direct traceable costs such as Salary \& Wages expenses, Printing \& Stationary, and Telephone \& Fax and Freight \& Courier expenses. Other indirect costs of university which are fixed in nature, for instance Equipment leasing, Depreciation expenses, Utility expenses and supplies are not shown in the budget neither are they absorbed into department budgets. In addition, neither direct cost nor indirect cost is disseminated to other sub divisions of the department as per activitiy that drives the cost. This approach gives very little costing information about the department's activities that drive the cost and, therefore, it is not effective way of cost monitoring. Thus, the disadvantage of the university's current costing model is that true cost \& effectiveness of resources is unknown, it is difficult to fit mandated activities within shrinking budget envelopes and the system is not an appropriate tool as a performance measurement framework.

As a result, the university requires an alternative costing model that goes beyond the first stage cost allocation to the second stage of cost allocation, whereby the costs are further allocated per activity that drives the cost. The present university costing system only does the first stage allocation and not the second. The suggested costing system based on Activity- Based Costing (ABC) is a better form of costing system that meets the demand of the university for continuous improvement and manages business process.

\section{NEW COST STRUCTURE}

\section{ABC Cost Model}

The analysis of departmental activities is the first step of designing the system. Lambert and Whitworth (1996) noted that the building block of an ABC system is the analysis of activities in order to identify the following: the activities within each department and why, and under what circumstances each activity is done; how often, and for whom, the activity is performed; resources consumed in doing the activity; and, what factors determine or "drive" the activity or resource. Similar to the manufacturing environment, every activity in service organization can be classified into four areas, I) Unit Activities, performed on units of products, II) Batch Activities, performed on batches of products rather than individual product unit, III) Product Activities, benefit all units of a product and finally IV) Facility and Organizational Activities, facilities activities are incurred only to support the ongoing facility operations. For this case study the analysis of division activities focuses at Student service Department and the activity classification is shown in Table 1. 
Table 1

\begin{tabular}{|c|c|c|}
\hline \multicolumn{3}{|c|}{ Resource Center: Student Service Department } \\
\hline Activity Center & Activity & $\begin{array}{c}\text { Activity } \\
\text { Classification }\end{array}$ \\
\hline 1) Student Affair Division & $\begin{array}{l}\text { - Personal Counseling } \\
\text { - Orientation Week } \\
\text { - University Social Activity } \\
\text { - Career Placement } \\
\text { - Graduation }\end{array}$ & Unit \\
\hline 2) International Student Division & - Visa / Permit & Batch \\
\hline 3) Housing Division & $\begin{array}{l}\text { - On campus and Off campus } \\
\text { accommodation }\end{array}$ & Unit \\
\hline $\begin{array}{l}\text { 4) Admission and Enrolment } \\
\text { Division }\end{array}$ & $\begin{array}{l}\text { - University Enrolment } \\
\text { - Update students academic record }\end{array}$ & $\begin{array}{l}\text { Unit } \\
\text { Batch }\end{array}$ \\
\hline 5) Examinations Division & $\begin{array}{l}\text { - Academic Result } \\
\text { - Examination rules and Procedures } \\
\text { - Invigilation Duties } \\
\text { - Unit Examination }\end{array}$ & $\int_{\text {Batch }}^{\text {Unit }}$ \\
\hline
\end{tabular}

The next stage is developing cost assignment model for the univesity using the ABC costing system. The model shown in Figure 1 is adopted from Turney (cited in Compton, 1996) and modified to suit all the departments at the University. The model consists of the following elements: -

Resources

Activity center

Resources Drivers

Activity Cost Pool

Cost Driver

Cost Elements

Cost Object
Economic elements used to perform activities.

A cluster of related activities

Factors used to allocate resource or pools of costs to activities

Total cost assigned to an activity

A factor used to assign cost from an activity enter to other activity cost pools or cost objects

The amount paid for a resource and assigned to an activity The ultimate goal for performing an activity, and in ABC it represents the final cost assigned to a product or service.

The department's organization chart in the university is a good starting point to convert to ABC cost model elements. The Student Service Department at Registrar's office chart was literally transformed into an ABC operational model as shown in Figure 2.

Analyzing and identifying the drivers are important tasks in the ABC costing system. There are two types of drivers namely 1) Resource Driver and 2) Cost or Activity Driver. 
Resource Drivers are the links between the resources and the activities. As shown in Figure 2 the resource driver allocates the total budget of registrar office division to each resource center; which is the Student Service Department. The resource driver is also used to disseminate the Student Services budget to other sub division of the student service department. The resource driver (allocation base) is used for the selected general ledger items is shown in table 2.

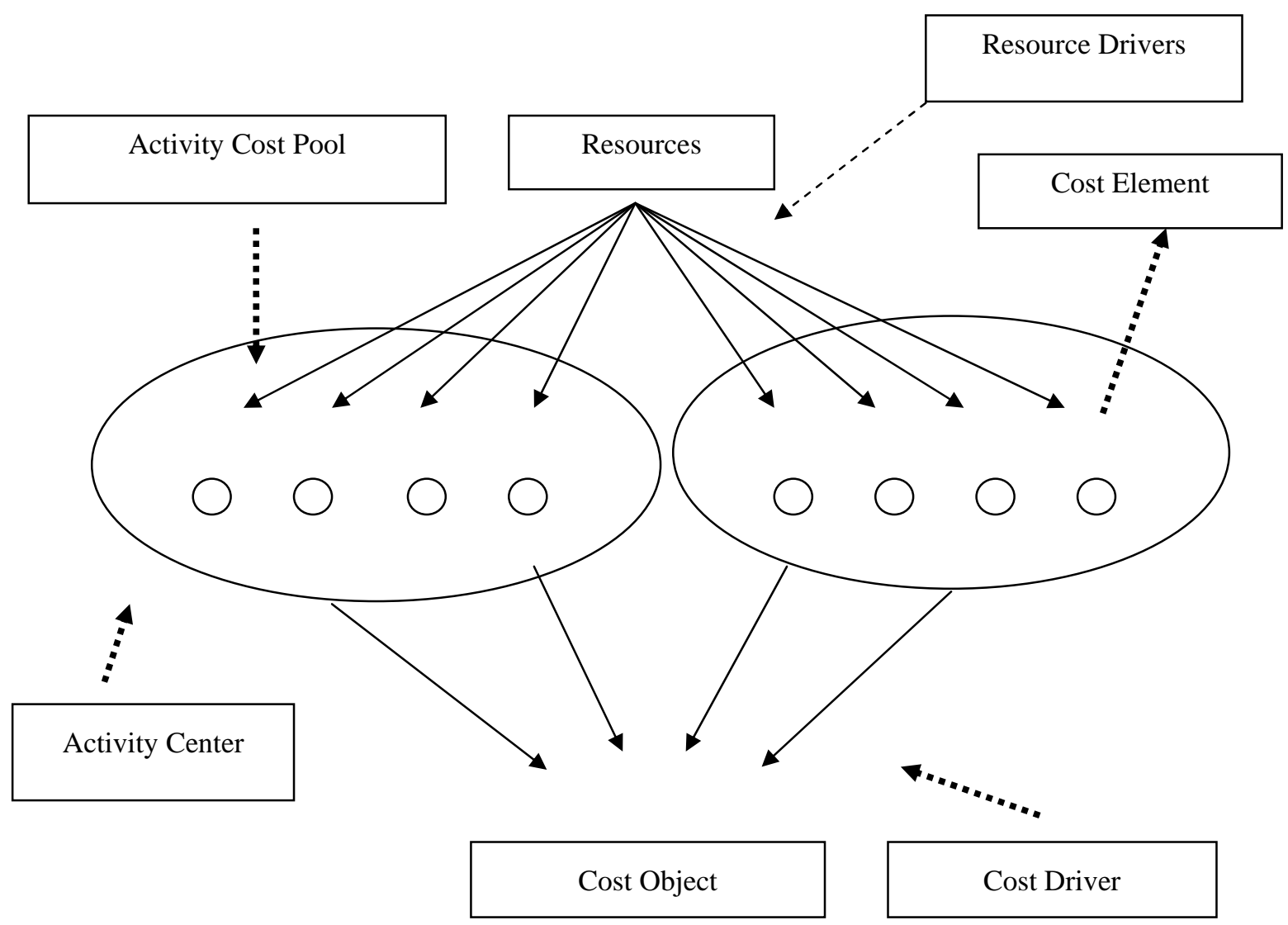

Figure 1 ABC Cost Assignment Model 


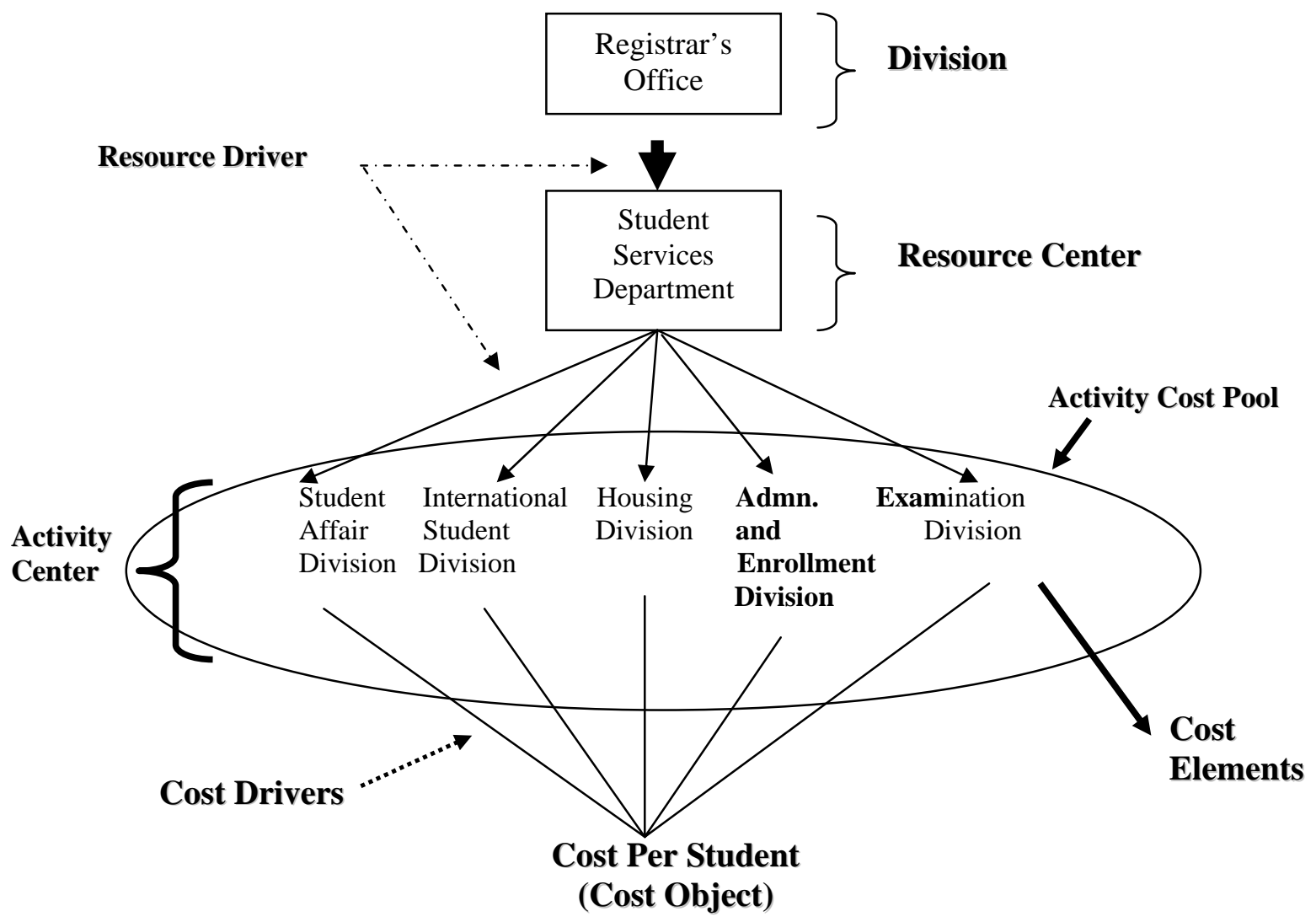

Figure 2 ABC model for Student Service Department at Registrar’s Office

Once the general ledger item (cost pool) and its related cost are allocated to the resource center i.e. Student Service Department, the resource driver will disseminate each cost element to other activity centers at the Student Service Department such as examination division, student affair division, housing division and etc. The allocation of cost to each activity center depends on activities that are performed. Any activities that are not related to the specific cost elements are eliminated, as those activities do not add values to the ultimate goal of the division. For example, cost pools such as Graduation, Orientation and Visa \& Permit expenses listed in the Student Service Department are eliminated from the Admission and Enrollment activity center as this division does not perform any activities related to this expense (refer to Table 1). However, this was not the case under the university's traditional costing system whereby cost pools were not classified according to the activity performed by each activity center. The university's traditional costing system does not eliminate non 
added value activities and, thus, this method does not give accurate - 'true' cost information to the department head to have better control over the costs.

Table 2 Resource Driver

\begin{tabular}{|l|r|l|}
\hline \multicolumn{1}{|c|}{ General Ledger Items } & Amount (RM) & \multicolumn{1}{|c|}{ Allocation Base } \\
\hline Freight and Courier & 214,000 & Traced \\
\hline Graduation Expenses & 22,300 & Traced \\
\hline Orientation Expenses & 6,600 & Traced \\
\hline Printing \& Stationery & 18,000 & Allocated by estimated \\
\hline Telephone \& Faxes & 5,000 & No Calls and Faxes \\
\hline Transportation - General & 1,000 & Allocated \\
\hline Traveling Expenses & 4,600 & Allocated \\
\hline Visa/Permit & 3,000 & Traced \\
\hline Salaries \& Wages & 348,200 & Traced \\
\hline EPF & 41,800 & Traced \\
\hline SOCSO & 1,000 & Traced \\
\hline Payroll Taxes & 60,000 & $10 \%$ of Wages \\
\hline Equipment Leasing & 30,000 & $10 \%$ of Wages \\
\hline Depreciation Expenses & 40,000 & By Floor Space \\
\hline Utility Expenses & 30,000 & By Floor Space \\
\hline Supplies & 50,000 & Allocated by estimates \\
\hline Total & $\mathbf{8 7 5 , 5 0 0}$ & \\
\hline
\end{tabular}

There are a total of five sub-division of activity center in the student service department, namely Student Affair Division, International Student Division, Housing Division, Admission \& Enrolment Division, and Examination Division, as shown in Table 1. For the purpose of illustrating ABC allocation of cost pools' the Admission and Enrollment division is used as shown in Table 3 and 4.

The final stage of ABC model is calculating the cost pool rate. A pool rate is calculated by allocating the total of sub division cost to the cost object by using activity (cost) driver. The cost object represents a product and service that the organization generates revenue from. As for the university, the cost object is the student and the activity or cost driver is the number of students. The cost pool rate for Admission and Enrollment Division of Student Service Department in the Registrar's Office is shown in Table 5. 
Table 3 Assignment of Costs from Registrar's office (Division) to Student Service Departments(Resource Center)

\begin{tabular}{|l|r|l|r|}
\hline \multicolumn{1}{|c|}{ Cost Pool } & Amount (RM) & \multicolumn{1}{c|}{ Resource Driver } & $\begin{array}{c}\text { Student Service } \\
\text { Department }\end{array}$ \\
\hline Freight and Courier & 214,000 & Traced & 18,000 \\
\hline Graduation Expenses & 22,300 & Traced & 22,300 \\
\hline Orientation Expenses & 6,600 & Traced & 6,600 \\
\hline Printing \& Stationery & 18,000 & Allocated by estimated & 12,000 \\
\hline Telephone \& Faxes & 5,000 & No Calls and Faxes & 3,000 \\
\hline Transportation - General & 1,000 & Allocated & 800 \\
\hline Traveling Expenses & 4,600 & Allocated & 2,000 \\
\hline Visa/Permit & 3,000 & Traced & 3,000 \\
\hline Salaries \& Wages & 348,200 & Traced (40\%) & 139,280 \\
\hline EPF & 41,800 & Traced (40\%) & 16,720 \\
\hline SOCSO & 1,000 & Traced (20\%) & 200 \\
\hline Payroll Taxes & 60,000 & $20 \%$ of Wages & 27,856 \\
\hline Equipment Leasing & 30,000 & $10 \%$ of Wages & 13,928 \\
\hline Depreciation Expenses & 40,000 & By Floor Space & 25,000 \\
\hline Utility Expenses & 30,000 & By Floor Space & 18,750 \\
\hline Supplies & 50,000 & Traced & 20,000 \\
\hline Total & $\mathbf{8 7 5 , 5 0 0}$ & & $\mathbf{3 2 9 , 4 3 4}$ \\
\hline
\end{tabular}

Table 4 Assignment of Costs from Student Service Center (Resource Center) to Admission and Enrollment Division (Activity Center)

\begin{tabular}{|l|r|l|r|}
\hline \multicolumn{1}{|c|}{ Cost Pool } & Amount (RM) & \multicolumn{1}{|c|}{ Resource Driver } & $\begin{array}{c}\text { Cost Assignment to A } \\
\text { \& E Division. }\end{array}$ \\
\hline Freight and Courier & 18,000 & Traced & 12,000 \\
\hline Printing \& Stationery & 12,000 & Allocated by estimated & 8,000 \\
\hline Telephone \& Faxes & 3,000 & No Calls and Faxes & 2,000 \\
\hline Transportation - General & 800 & Allocated & 200 \\
\hline Traveling Expenses & 2,000 & Allocated & 800 \\
\hline Salaries \& Wages & 139,280 & Traced (15\%) & 20,892 \\
\hline EPF & 16,720 & Traced (15\%) & 2,508 \\
\hline Payroll Taxes & 27,856 & $20 \%$ of Wages & 4,178 \\
\hline Equipment Leasing & 13,928 & $10 \%$ of Wages & 19,089 \\
\hline Depreciation Expenses & 25,000 & By Floor Space & 13,500 \\
\hline Utility Expenses & 18,750 & By Floor Space & 8,000 \\
\hline Supplies & 20,000 & Traced & $\mathbf{9 3 , 6 6 7}$ \\
\hline Total & $\mathbf{2 9 7 , 3 3 4}$ & & \\
\hline
\end{tabular}


Table 5 Admission and Enrollment Division's cost pool rate.

Activity Center Cost Pool $/$ Cost Driver $=$ Cost Pool Rate

$\$ 93,667$ / 1640 students $=\$ 57.11$ per students.

The service cost of Admission and Enrollment division per students is \$57.11.

The ultimate purpose of $\mathrm{ABC}$ system is to assign every activity cost incurred to product or service. As in the university case the cost is assigned to student as each activity center incurred cost as a result of service rendered to the students. The ABC cost activity analysis shows clearly to the department head how much cost is incurred by the division in performing services for each student and to know whether this cost is justifiable to provide the service. This system also eliminates non added value activities as discussed above to show the true cost that the division incurred. Finally this cost can also be used as a performance evaluation tool to evaluate the division performances from one year to another.

\section{RECOMMENDATION AND CONCLUSION}

Determining the true cost plays an important role in strategic decision-making. The $\mathrm{ABC}$ system provides more accurate cost management and enables the university managers to calculate the 'true' cost of a product i.e. cost per students. It is crucial for effective implementation of the system that the $\mathrm{ABC}$ project team must be released from normal duties and the university must prepare to invest in computer technology. ABC information system is widely available for an effective use of $A B C$ system in the organization. However, Compton (1996) noted that internal control must be placed in order to avoid any unauthorized users to make modifications to data in the system. This is especially true if $\mathrm{ABC}$ replaces the existing cost accounting system that has been traditionally used for supplying information for financial reporting purposes (ibid). Therefore, a special monitoring personnel is employed to administer the database. In addition to this input, processing and output controls are established in order to control changes and access.

In a nutshell, the $\mathrm{ABC}$ system clearly indicates that it can help the university to understand where the costs are, what drives them to occur, and which costs may be lowvalue-added to the cost object. The system enables the department heads of the university to analyze and see things, through the lens of costs and work activities. This definitely will replace their decision-making behavior through intuition and assertions to fact-based. Therefore, the big opportunities of ABC system predicting planning, cost estimation and 
elimination of non-added value activities, which are useful for operational strategic decision.

\section{REFERENCES}

Adams, M. (1996). Activity-based costing (ABC) and the Life Insurance Industry. The Service Industries Journal, 16 (4), 511-526.

Baird, K.M., Harrison, G.L., \& Reeve, R.C. (2004). Adoption of activity management practices: a note on the extent of adoption and the influence on organizational and cultural factors. Management Accounting Research, 15, 323-399.

Brignall,S. (1997). A contingent rationale for cost system design in service. Management Accounting Research, 8, 325-346.

Cagwin, D. \& Bouwman, M.J. (2002). The association between activity-based costing and improvement in financial performance, Management Accounting Research, 13, 1- 39.

Cotton, W.D.J., Jackman, S.M. \& Brown, R.A. 2003. Note on a New Zealand replication of the Innes et al. UK activity - based costing survey. Management Accounting Research, 14, $67-72$.

Cokins,G. (1998). Why is traditional Accounting Failing Managers? AACE International Transactions, 11-15.

Compton. T.R. (1996), Implementing activity-based costing. The CPA Journal, 66 (3), 20-27.

Estrin, T.L., Jeffrey, K. \& David, A. (1994). Is ABC suitable for your company.. Management Accounting, 75 (10), 40 - 45.

Hilton,R.W.(2005).Managerial Accounting -Creating value in a dynamic business environment. New York: McGraw-Hill Irwin.

Horgren, C.T. (1995). Management accounting: this century and beyond . Management Accounting Research, 6, 281-286.

Hoshower,L.B., Compton, T.R. \& Meddaugh, E.J. (1996) As Simple as ABC. Ohio CPA Journal, 55 (4), 50-56.

Ibrahim, M.Y., Idris, K.M. \& Hassan, A.H. (2001). Measuring the performance of a service organization using activity analysis: A local case study. Akauntan Nasional, $8-12$.

Innes, J. \& Mitchell, F. (1997). The application of Activity-based costing in the United Kingdom's Largest Financial Insititutions. The Service Industries Journal, 17 (1), 190-203.

Kock, S. (1995). Implementation consideration for activity-based costing system in 
service firms: the unavoidable challenge. Management Decision, 33 (6), 57-63.

Kullven, H. \& Mattson, J. (1994). A management control model based on the customer service process, International Journal of Service Industry Management, 5 (3), 1425.

Lambert, D. \& Whitworth, J. (1996). How ABC can help service organizations, CMA,70, 24-28.

McGowan, A.S. (1998). Perceived Benefits of ABCM Implementation. Accounting Horizons, 12 (1), 31-50.

Robert, S.K. (1992). In defense of Activity-Based Cost Management. Management Accounting, 74 (5) 58-63. 
